\title{
Considerations regarding the particularities of orthodontic treatment in adults
}

\author{
Consideraţii privind particularităţile tratamentul ortodontic la adulţi
}

\author{
Mioara Decusară, Cerasella Dorina Şincar, Gabriel Valeriu Popa \\ Departamentul de Medicină Dentară, Facultatea de Medicină şi Farmacie, \\ Universitatea „Dunărea de Jos“, Galaţi, România
}

\begin{abstract}
Introduction. Adult patients frequently require orthodontic treatment for dental alignment that provides a beauti-ful, "healthy" smile that gives a pleasant facial aspect, increased self-confidence, and psycho-socioprofessional integration. Most often the patients 25 to 40 years old want to have "straight" teeth because they refused the orthodontic treatment in their childhood and adolescence or had no financial possibilities for it at that moment. Adults over the 40 years age require orthodontic treatment either on their own initiative due to migrations or dental maloclussion, or at the recommendation of specialists in periodontics, prosthetics, implantology, for complex oral rehabilitation.

Clinical case. The case of a 45-year-old patient, who requested the orthodontic treatment for aesthetic reasons, to correct dental malpositions resulting from bone generalized horizontal atrophy with moderate reduction in periodontal attachment.

Conclusions. Compared to other dental treatments where results are visible in a relatively short time orthodontic therapy requires an average duration of 18-24 months, depending on age, home environment, severity of dento-maxillary abnormality, genetic predisposition, vicious habits, etc. It is important to establish a correct diagnosis for a proper treatment plan with reduction of risks, complications and orthodontic relapse.
\end{abstract}

Keywords: dental migration, bone generalized atrophy, adult orthodontic treatment

\section{REZUMAT}

Introducere. Pacienţii adulţi solicită frecvent tratament ortodontic pentru alinierea dentară care asigură un zâmbet frumos, „sănătos“, care determină un aspect facial plăcut, creşterea încrederii în sine şi integrare psiho-socio-profesională. De cele mai multe ori, pacienţii între 25 şi 40 de ani vor dinţi „drepţi“", deoarece în copilărie şi adolescenţă au refuzat tratamentul ortodontic sau nu au avut atunci posibilităţi financiare pentru acesta. Adulţii peste 40 de ani solicită tratament ortodontic fie din proprie iniţiativă, din cauza migrărilor sau malpoziţiilor dentare, fie la recomandarea specialiştilor în parodontologie, protetică, implantologie, pentru reabilitare orală complexă.

Caz clinic. Este prezentat cazul unei paciente de 45 de ani, la care motivul solicitării tratamentului ortodontic a fost de ordin estetic, pentru corectarea malpoziţiilor dentare apărute ca urmare a atrofiei osoase orizontale generalizate, cu reducerea moderată a gradului de ataşament parodontal.

Concluzii. Comparativ cu alte tratamente stomatologice la care rezultatele sunt vizibile într-un timp relativ scurt, terapia ortodontică necesită o durată medie de 18-24 de luni, în funcţie de vârstă, mediul de provenienţă, gravitatea anomaliei dento-maxilare, predispoziţii genetice, obiceiuri vicioase etc. Stabilirea unui diagnostic corect este importantă pentru un plan de tratament corect, cu reducerea riscurilor, complicaţilor şi a recidivei ortodontice.

Cuvinte cheie: migrări dentare, atrofie osoasă generalizată, tratament ortodontic la adult

\section{INTRODUCERE}

$\mathrm{Ca}$ orice act terapeutic, tratamentul ortodontic poate prezenta riscuri şi complicații, reprezentate de apariţia leziunilor carioase, a petelor albe de de- mineralizare, resorbții radiculare, probleme parodontale. Aceste leziuni nu sunt întotdeauna induse de deficienţe terapeutice, de importanţâ majoră fiind diagnosticul complet şi corect, care stă la baza oricărui tratament $(1,2)$. 
Diagnosticul permite evaluarea situației parodontale, riscul terapeutic parodontal, stabilind astfel limitele tratamentului ortodontic. Sub acest aspect, sunt importante datele culese din anamneza pacientului şi examinarea clinică locală: vârstă, sex, mediul de proveniență, igienă dentară, status odontal şi dentar (leziuni carioase,malpoziții dentare).

- factori sociali şi de comportament (tabagism, obiceiuri alimentare, profesie);

- factori genetici (predispoziții genetice);

- factori sistemici (diabet, boli cardiovasculare, dislipidemii, tratamente medicamentoase: cortizon, antiepileptice, imunosupresoare etc.) $(3,4)$.

În astfel de situații, este necesară evaluarea calității parodontale, care orientează deciziile terapeutice (extracții, chirurgie), dar mai ales tratamentul ortodontic, prin limitarea forțelor ortodontice şi a anumitor mişcări dentare (extruzie, intruzie, translații, versii) pe un teren parodontal sănătos, fără inflamații (5).

Important în deciziile terapeutice ortodontice este şi motivul pentru care pacientul se prezintă pentru consult. De cele mai multe ori, motivația este dată de malpozițiile dentare (egresii, rotații, diasteme), care determină modificarea esteticii faciale şi a zâmbetului pacientului (6).

\section{PREZENTAREA CAZULUI}

Pacienta G.M., de 45 de ani, din mediul rural, s-a prezentat pentru corectarea ortodontică a poziției incisivilor superiori, invocând motive estetice, dar şi funcționale. La anamneză, pacienta a declarat că, de aproximativ 5 ani, dinţii de la ambele arcade au căpătat o uşoară mobilitate, care a determinat vestibularizarea incisivilor superiori, cu apariția de treme şi diastemă. Starea de sănătate era bună, ne- fumătoare, fără suferințe generale acute sau cronice pentru care să urmeze un tratament medicamentos.

Examinarea din normă frontală evidențiază fața ovală, simetrică, cu păstrarea proporției între etajele figurii. Din normă laterală, profilul era drept, cu treapta labială normală. La examenul ATM, nu au fost semnalate fenomene patologice, iar deschiderea gurii era în limite normale, fără devieri ale mentonului şi fără zgomote articulare.

La examenul endobucal s-au constatat (Fig. 1):

- leziune carioasă în foseta vestibulară de la nivelul lui 36, tratată cu obturație de compozit fotopolimerizabil;

- edentație laterală redusă maxilară dreapta determinată de extracția lui 16 , neprotezată;

- edentație laterală redusă mandibulară dreapta, tratată prin punte metalo-ceramică fizionomică;

- frenul labial superior cu inserție joasă, până în vecinătatea papilei interincisive;

- diastemă superioară de $3 \mathrm{~mm}$ şi treme între 12 şi 11 şi între 43 şi 42 de $1 \mathrm{~mm}$;

- vestibulo-înclinarea incisivilor superiori, cu ocluzie labiodontă şi supracoperire frontală de $3 \mathrm{~mm}$;

- angrenaj invers 13 cu 43 şi 44, ceea ce limitează mişcările funcționale mandibulare de propulsie şi lateralitate;

- rapoarte ocluzale molare şi canine clasa I Angle bilateral;

- retracție gingivală la nivelul incisivilor, mai accentuată la nivelul lui 31, cu semne inflamatorii determinate de tartru;

- mobilitate dentară moderată, în sens vestibulo-oral, la nivelul incisivilor mandibulari.

Ortopantomograma evidențiază (Fig. 2):

- tratamente radiculare la nivelul dinților stâlpi protetici 45 şi 47 ;

- rădăcinile lui 15 şi $25 \mathrm{cu}$ aspect, ,în baionetă“, ocolind parcă podeaua cavităților sinusale
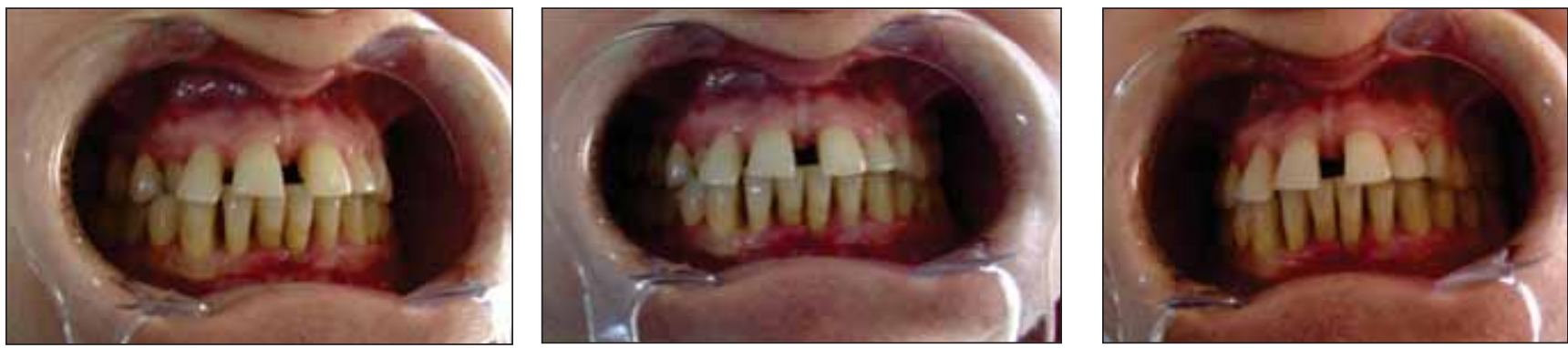

FIGURA 1. Vedere din normă frontală şi laterală a arcadelor dentare în ocluzie statică 


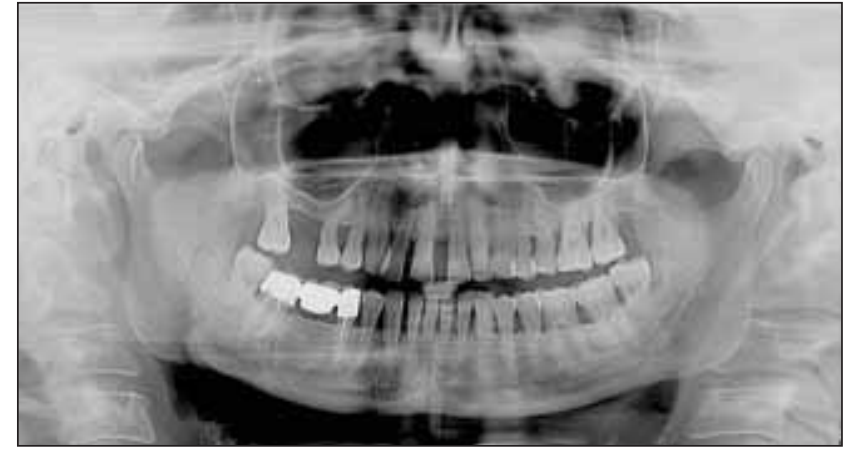

FIGURA 2. Ortopantomograma pacientei la începutul tratamentului ortodontic

- 48 în supraocluzie, în egresie spre spaţiul edentat distal de 17;

- atrofie osoasă orizontală generalizată moderată, cu pierderea ataşamentului parodontal până la nivelul furcațiilor rădăcinilor molarilor.

Având în vedere motivele de ordin estetic pentru care pacienta a fost consultată, tratamentul ortodontic a urmărit:

- corectarea angrenajului invers 13 cu 43 şi 44;

- închiderea spațiilor interdentare şi reducerea gradului de vestibularizare a incisivilor maxilari;

- menținerea corespondenței liniilor mediane şi interincisive, a supraacoperirii frontale inițiale şi a relațiilor neutrale molare şi canine, bilateral.

Tratamentul ortodontic s-a realizat cu aparat ortodontic metalic fix bimaxilar, straight wire tech- nique, cu ajutorul căruia s-au obținut obiectivele terapeutice menționate mai sus (Fig. 3). De la începutul tratamentului ortodontic, s-a avut în vedere gradul de atrofie osoasă orizontală generalizată, care a determinat modificarea centrului de rezistență al dinţilor spre apex şi implicit creşterea intensității mişcării de versie dentară. Ca urmare, pe toată perioada tratamentului, s-a utilizat o biomecanică prin care s-a menținut constant raportul forță/moment, intensitatea forțelor ortodontice a fost de intensitate redusă şi constant, astfel încât să se evite crearea de zone de hialinizare care ar fi agravat statusul parodontal existent.

Durata tratamentului ortodontic a fost de $20 \mathrm{de}$ luni, igiena dentară a pacientei a fost satisfăcătoare, iar contenția s-a realizat cu fir colat lingual canincanin la mandibulă şi gutieră termoformabilă de contenție la maxilar.

La analiza ortopantomogramei, efectuată după îndepărtarea aparatului ortodontic, s-a constatat obținerea paralelismului radicular al dinților maxilari, fără resorbții radiculare patologice şi fără agravarea atrofiei osoase orizontale existente (Fig. 4).

\section{CONCLUZII}

În ortodonția actuală, pacienții adulți solicită din ce în ce mai des tratament ortodontic pentru alinierea dentară, la bază fiind contextul social în care surâsul şi estetica facială ocupă un loc important în
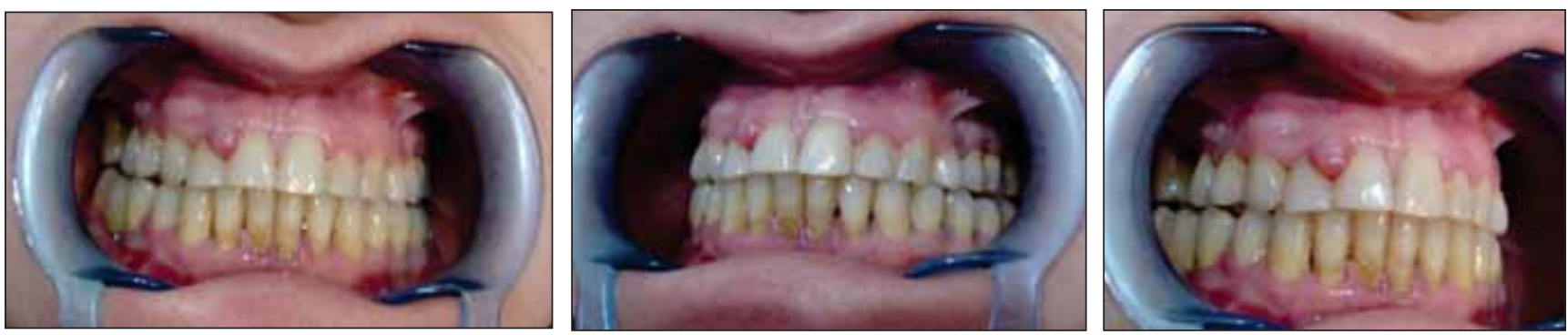

FIGURA 3. Imaginea arcadelor dentare în ocluzie statică la finalul tratamentului ortodontic

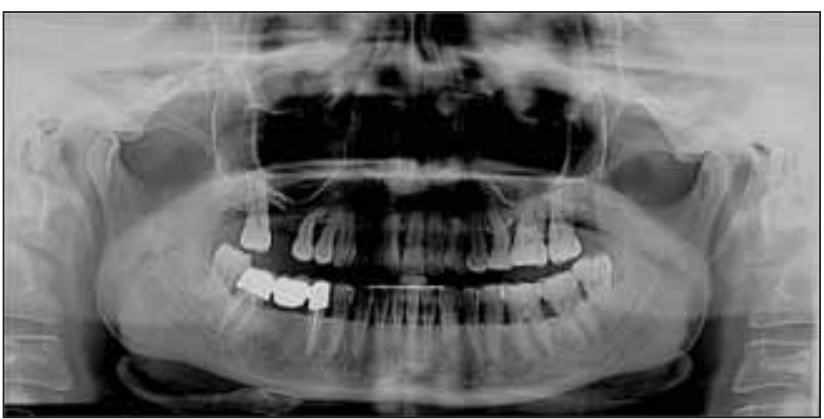

FIGURA 4. Ortopantomograma pacientei la finalul tratamentului ortodontic, după îndepărtarea aparatului fix 
reuşita psiho-profesioală. Principiile tratamentului ortodontic la adult sunt asemănătoare cu cele ale tratamentului la copii şi adolescenți, dar țin cont întotdeauna de factorii psihologici, biologici şi de diagnostic specifici adultului. Medicul specialist ortodont trebuie să analizeze motivele pacientului, să

\section{BIBLIOGRAFIE}

1. Melsen Birte. Adult orthodontics, BlackWell Publishing Ltd., 2012

2. Kokich V.G. Adult orthodontics in the 21th century: Guidelines for achieving successful results. World Journal Orthod 2005; 6 Suppl:14-13.

3. Ogodescu Al. Tratamentul ortodontic la adult, Ed. Eubeea, 2008

4. Heasman and Millett. The Periodontium and Orthodontics in Health and Disease. Oxford University Press, 1996.

5. Şincar Dorina-Cerasella, Leaţă R., Popa G.V., Decusară Mioara, Earar K. Clinical study of periodontal îi explice posibilitățile şi limitele tratamentului ortodontic şi să adapteze terapia în funcție de statusul dentar, ocluzal, parodontal, al țesuturilor moi şi structure osoase, de cele mai multe ori în colaborare cu specialişti în parodontologie, protetică, implantologie şi chirurgie dentară $(7,8)$.

Conflict of interest: none declared Financial support: none declared

parameters during the orthodontic treatment, Romanian Journal of Oral Rehabilitation, 2018, 10(2), 26-31.

6. Proffit W.R. Contemporary orthodontics, Mosby, 2007

7. Decusară Mioara, Şincar Dorina-Cerasella, Rusu Magdalena, Nicolau A.M. Therapeutical considerations on the orthodontic preprosthetic treatment, Analele Universităţii „Dunărea de Jos“ Medicină, 2016, XVII(2):13-16, ISSN: 2344-4428.

8. Decusară Mioara. Utilizarea ortopantomogramei în practica stomatologică, Galaţi, Editura Zigotto, 2017. 